\title{
FAKTOR RASIO KEUANGAN TERHADAP SUSTAINABILITY PERBANKAN DI INDONESIA: MENGGUNAKAN REGRESI LOGISTIK
}

\author{
Titis Miranti ${ }^{1}$ \\ Email:mirantititis@gmail.com
}

\begin{abstract}
This study aims to look at the variables that affect financial sustainability. The data used are banking financial statement data contained in the FSS in 2013 to 2017. The value used to measure financial sustainability is FSS. The value of FSS as the dependent variable is divided into two categories, namely banks that are sustainable and banks that are not sustainable. Response variables used are financial ratios consisting of ROA, ROE, CTD, LTD, DTA, and CTA. The analysis used is logistic regression. Based on the results of the logistic regression model that is formed, a significant variable influences sustainability is ROA and LTA. The odds ratio values for the ROA and ROE variables are 1.2 and 2.2. This means that there is an increasing trend of 1.2 and 2.2 times for better financial sustainability with each added value of ROA and ROE. In other words, the greater the value of ROA or ROE, the greater the possibility of banking for financial sustainability. Chi-square test shows the p-value of 0.27 is greater than alpha. This shows the model meets the goodness of fit.
\end{abstract}

Keywords: Financial Sustainability, Financial Ratio, Logistic Regression, Odds Ratio

\section{PENDAHULUAN}

Krisis keuangan global yang terjadi pada tahun 2007-2008 mengakibatkan beberapa bank konvensional kengalami kegagalan keuangan. Akan tetapi hal ini berbeda dengan bank syariah yang telah berhasil mengatasi krisis tersebut. Studi yang dilakukan oleh (Hasan dan Dridi, 2011) menyatakan bahwa keberhasilan bank syariah dalam mengadapi krisis adalah disebabkan prinsip-prinsip syariah yang dianut oleh bank syariah, salah satunya yaitu menghindari pembayaran dan penerimaan riba. Pesatnya pertumbuhan keuangan di bank syariah didukung dengan produk-produk syariah yang ditawarkan oleh bank syariah, diminatinya produk oleh masyarakat, dan juga peranan pemerintah dalam mempayung hukumi bank syariah juga dibangun dengan baik sesuai syariah islam dan tidak melanggar aturan Negara.

${ }_{1}$ Corresponding author: Universitas Islam Negeri Maulana Malik Ibrahim Malang 
Indonesia sebagai salah satu negara yang didalamnya terdapat dua jenis perbankan, yaitu bank konvensional dan bank syariah menjadikan peneliti untuk berlomba mencari celah karakteristik dari setiap jenis bank. Kedua jenis bank syariah dan konvensional dan merupakan bagian penting dalam upaya meningkatkan laju pertumbuhan perekonomi suatu negara. Bank sebagai wadah masyarakat untuk mengumpulkan dan mendistribusikan harta masyarakat. Masyarakat yang membutuhkan dana dapat terbantu dengan adanya perbankan, meskipun dengan beberapa syarat yang harus dapat dipenuhi. Masyarakat yang mampu memberdayakan diri untuk berusaha atau berwirausaha dapat memperkuat stabilitas perekonomian Indonesia. Oleh sebab itu, peranan perbankan menjadi sangat penting di Indonesia.

Peranan perbankan sebagai salah satu penunjang perekonomian Indonesia mengharuskan perbankan untuk terus dapat sustain atau mengalami keberlanjutan keuangan. Beberapa penelitian terkait peranan sustainability perbankan terhadap perekonomian Indonesia juga telah dilakukan oleh beberapa peneliti. (Sho'imah, Darminto, dan Nuzula, 2015) melakukan penelitian bahwa kinerja keuangan sebagai indikator keberlanjutan keuangan mampu dilihat dari rasio keuangan. Lebih dari itu, rasio keuangan juga digunakan sebagai indikator kinerja keuangan dalam mempengaruhi pertumbuhan ekonomi (Rafsanjani dan Sukmana, 2014; Ayyubi, Anggraeni, dan Mahiswari, 2017 ).

Secara teori, ada banyak perbedaan antara bank konvensional dan syariah. Sebagai contoh, kontrak bunga di bank konvensional diganti di bank syariah dengan kontrak bagi hasil, di mana keuntungan dan kerugian serta risiko dibagi antara mitra. Selain itu, bank syariah mengumpulkan dana melalui giro dan deposito investasi. Akan tetapi kondisi sebenarnya tidak sebenar-benarnya sesuai dengan teori. (Chong dan Liu, 2009) dan (Khan, 2010) menemukan bahwa hanya sebagian kecil dari pembiayaan bank syariah didasarkan pada prinsip bagi hasil dan deposito syariah tidak bebas bunga. (Bourkhis \& Nabi, 2013) menunjukkan bahwa di sebagian besar bank syariah, kurang dari $20 \%$ dari total aset didedikasikan untuk investasi jangka panjang dan pembagian risiko.

(Saragih, 2013) melakukan penelitian yang bertujuan untuk menganalisis perbandingan kinerja keuangan antara bank konvensional dan syariah. Metode yang digunakan adalah uji beda rata-rata atau (independent sample t-test). Hasilnya adalah variabel ROE, variabel ROA, dan LDR tidak berbeda signifikan antara perbankan syariah dengan perbankan konvensional, sebaliknya rasio CAR yang menunjukkan perbedaan signifikan antara perbankan syariah dan perbankan konvensional. Teknik yang sama juga digunakan oleh (Vivin dan Wahono, 2017). Penelitian tersebut menunjukkan bahwa Bank Umum Syariah lebih baik kinerjanya dari segi rasio NPL, rasio LDR, dan BOPO, sedangkan Bank Umum Konvensional lebih baik kinerjanya dari segi rasio CAR serta ROA. Analisis perbedaan kinerja keuangan bank syariah dan bank konvensional juga dilakukan (Thayib, Murni, dan Maramais, 2017).

Salah satu metode untuk melihat keberadaan perbedaan adalah dengan menggunakan analisis klasifikasi dan regresi. Metode klasifikasi dibagi menjadi dua yaitu klasifikasi dengan pendekatan parametrik dan non-parametrik. Regresi Logistik merupakan bagian dari analisis regresi yang dapat mengatasi untuk variable dependen berupa data kategoik. Sehingga dalam penelitian ini, peneliti ingin mengkaji faktor penentu bank syariah dan bank konvensional dalam mencapai sustainability atau keberlanjutan keuangan. 


\section{KAJIAN PUSTAKA}

Undang-Undang Perbankan Nomor 10 Tahun 1998 menyebutkan bahwa bank adalah badan usaha yang menghimpun dana dari masyarakat dalam bentuk simpanan dan menyalurkannya ke masyarakat dalam bentuk kredit dan/ atau bentuk lainnya dalam rangka meningkatkan taraf hidup rakyat banyak (Bank Indonesia, 1998).

Berdasarkan definisi tersebut, maka fungsi pokok dari bank adalah untuk menghimpun dana masyarakat dan menyalurkan kembali juga kepada masyarakat, sehingga bank disebut juga sebagai financial Intermediary. Bentuk penyaluran dana

dari bank kepada masyarakat dapat berupa pinjaman sepanjang persyaratan yang diajukan oleh bank dapat dipenuhi oleh peminjam. Bank juga disebut sebagai Financial Depository Institution atas kegiatannya dalam menghipun dana masyarakat yang belibih untuk disalurkan kepada masyarakat yang membutuhkan (Ismail, 2016).

Indonesia memberlakukan dual banking system, yaitu terselenggaranya dua system perbankan yaitu konvensional dan syariah secara bersamaan dan pelaksanaannya diatur oleh peraturan perundang-undangan yang berlaku di Indonesia

(Usanti dan Shomad, 2016). Bank Syariah dan bank konvensional mempunyai

beberapa perbedaan berdasarkan beberapa aspeknya, diantarnya dalam bidang investasi, return, perjanjian, orientasi pembiayaan, hubungan antara nasabah dengan bank, dewan pengawas dan penyelesaian sengketa (Ifham, 2015).

Definisi financial sustainability adalah alat ukur yang digunakan untuk menilai efisiensi suatu lembaga atau perusahaan. Rasio ini digunakan untuk mengetahui tingkat pertumbuhan lembaga tersebut setiap tahun ataupun periode sesuai dengan kebutuhan, serta dapat diketahui kinerja keuangan dari bank tersebut untuk mengambil keputusan apakah perlu melanjutkan operasionalnya atau tidak (Almilia dan Shonhadji, 2009). Kegunaan analisis financial sustainability ini yaitu sebagai indikator terhadap keberlanjutan suatu bank dan mengukur keberlanjutan suatu bank dari segi kinerja banknya.

Regresi logistik merupakan salah satu metode analisis statistika untuk menggambarkan hubungan antara variabel respon yang memiliki dua atau lebih kategori dengan satu atau lebih variabel penjelas yang berskala kategori atau interval (Hosmer dan Lemeshow, 2000). Analisis regresi logistik menghasilkan peubah yang bersifat biner dan dikotomi. Model regresi logistik biner digunakan jika peubah terikatnya menghasilkan dua kategori yang bernilai 0 dan 1 , sehingga mengikuti distribusi Bernoulli. Secara umum, persamaan regresi logistik sederhana (melibatkan satu variabel bebas) memiliki bentuk sebagai berikut.

$$
\ln \left[\frac{P(y=1)}{1-P(y=1)}\right]=\alpha+\beta x
$$

Perhatikan bahwa $P(y=1)$ menyatakan probabilitas terjadinya kejadian sukses (success), sedangkan $1-P(y=1)$ menyatakan probabilitas terjadinya kejadian gagal (failure). Rasio dari $\frac{p^{(y=1)}}{1-P(y=1)}$ disebut dengan odds.

\section{METODE}

Penelitian ini menggunakan jenis penelitian kuantitatif. Objektivitas desain penelitian sangat menentukan hasil penelitian. Desai penelitian kuantitatif lebih memaksimalkan pada angka-angka, pengolahan statistik, struktur dan percobaan terkontrol (Hamdi dan Bahruddin, 2014). Penelitian kuantitatif identik dengan pendekatan deduktif, yaitu dari persoalan yang bersifat umum (teori) ke bagian 
khusus sehingga penelitian ini harus ada landasan teorinya (Asnawi dan Masyhuri, 2011). Jenis pendekatan yang digunakan adalah pendekatan eksplanatori yaitu untuk memberikan penjelasan terhadap antar variabel maka dibutuhkan. Populasi yang digunakan merupakan seluruh bank umum konvensional dan bank syariah yang ada di Indonesia. Sampel yang diambil dengan menggunakan teknik purposive sampling. Kriteria tersebut adalah bank konvensional dan bank syariah yang melaporkan rasio finansialnya dalam periode 2013-2017.

Studi ini menggunakan data sekunder yang diadopsi dari beberapa web perbankan atau Bank Indonesia. Data sekunder ini merupakan laporan keuangan setiap bank setiap tahun pada periode tahun 2013 sampai dengann 2017. Variabel penelitian yang digunakan mengadopsi dari penelitian sebelumnya yang dilakukan oleh (Johnes, Izzeldin, dan Pappas, 2014). Penelitian tersebut menggunakana rasio keuangan sebagai pembeda atau pembentuk klasifikasi antara bank syariah dan bank konvensional. Adapun beberapa rasio yang digunakan adalah rasio profitabilitas, rasio likuiditas, angka resiko kredit, nilai asset, dan resiko insolvensi. Tabel 3.1 menunjukkan definisi variabel yang digunakan mulai dari simbolisasi dan formulanya.

Tabel 1. Variabel Penelitian

\begin{tabular}{llc}
\hline Variabel & \multicolumn{1}{c}{ Deskripsi } & \multicolumn{1}{c}{ Formula } \\
\hline FFS & Financial Self-Sufficiency & $\begin{array}{c}\text { Fixed Assets } \\
\text { Total Assets }\end{array}$ \\
\hline ROA & Return on Asset & $\begin{array}{c}\text { Net income } \\
\text { Total Assets }\end{array}$ \\
\hline ROE & Return on Equity & $\frac{\text { Net Income }}{\text { Stockholders'equity }}$ \\
\hline CTD & Cash to Deposits & Cash \\
\hline LTA & Loans to Assets & Total Customers Deposit \\
\hline DTA & Deposits to Assets & Total Assets \\
\hline CTA & Cash to Assets & $\frac{\text { Deposits }}{\text { Total assets }}$ \\
\hline
\end{tabular}

\section{HASIL DAN PEMBAHASAN}

\subsection{Karakteristik Data Penelitian}

Financial sustainability perbankan merupakan nilai kecukupan yang menjadi syarat suatu perbankan dapat dikatakan sustain atau berkelanjutan. Pada penelitian rasio financial sustainability diaproksimasikan kedalam nilai Financial SelfSufficiency (FSS). Nilai ambang batas variabel FSS adalah sebesar 100\%. Jika bank memperoleh nilai rasio FSS sebesar $100 \%$ atau lebih maka hal ini menunjukkan bahwa perbankan tersebut sustain. Akan tetapisebaliknya apabila rasio FSS dari perbankan tersebut kurang dari $100 \%$ maka perbankan dikatakan tidak sustain (Sylvanus, 2017). Penelitian ini menggunkan variabel-variabel keuangan yang diduga mempengaruhi nilai financial sustainability perbankan di Indonesia diantaranya ROA, CTD, LTA, dan DTA.

Gambar 1. mendeskripsikan di Indonesia berdasarkan kategori FSS pada tahun 2014 sampai tahun 2017. Jumlah sampel yang digunakan sebanyak 393 data. 
Terdapat 226 atau 57,5\% perbankan yang sustain dan 167 atau 42,5\% perbankan yang tidak sustain dan. Perbankan yang tidak sustain dari sampel tersebut antara lain BRI Syariah tahun 2014, Bank Syariah Mandiri tahun 2014, Bank Panin Dubai Syariah tahun 2016. Perbankan yang sustain dari sampel tersebut adalah Bank Danamon tahun 2017, BNI tahun 2014 dan 2017, Bank Bumi Artha tahun 2014 sampai 2017, BTPN tahun 2014 sampai 2017. Karakteristik selanjutnya adaah bagaimana nilai variabel penjelas dari perbankan yang sustain dan tidak berdasarkan nilai FSS. Karakteristik yang disampaikan meliputi nilai maksimal, minimla dan nilai rata-rata. Tabel 2. menunjukkan karakteristik variabel penjelas dari perbankan yang tidak sustain. Tabel 3. menunukkan karakteristik variabel penjelas dari perbankan yang sustain.

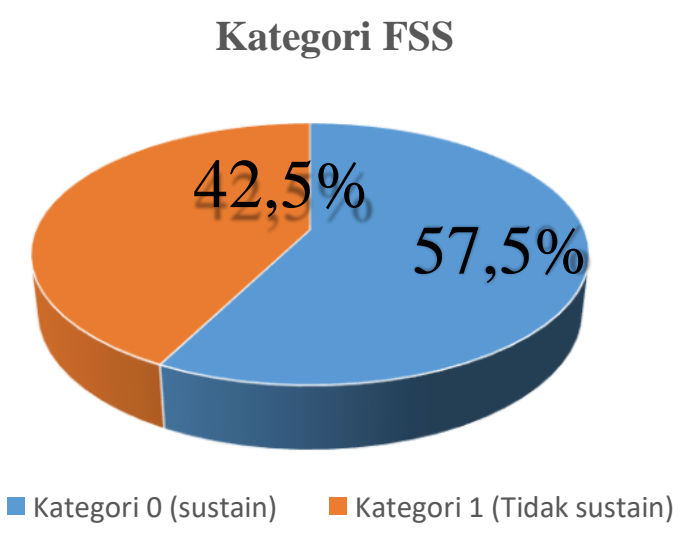

Gambar 1. Deskripsi FSS Perbankan di Indonesia

Tabel 2. Karakteristik Variabel Penjelas Perbankan Tidak Sustain

\begin{tabular}{lllll}
\hline \multicolumn{1}{c}{ Variabel } & \multicolumn{1}{c}{ Min } & \multicolumn{1}{c}{ Mean } & \multicolumn{1}{c}{ Median } & \multicolumn{1}{c}{ Max } \\
\hline ROA & -0.107700 & 0.012100 & 0.011800 & 0.111500 \\
ROE & 0.111500 & 0.05242 & 0.04405 & 0.83790 \\
CTD & 0.0009742 & 0.1796136 & 0.0805615 & 0.9302522 \\
LTA & -0.08815 & 0.41199 & 0.58337 & 0.88031 \\
DTA & 0.0000000 & 0.2522979 & 0.1388050 & 0.9575668 \\
CTA & 0.0003445 & 0.0724854 & 0.0127695 & 0.6970574 \\
\hline
\end{tabular}

Sumber Data: Hasil Pengolahan SPS

Tabel 3. Karakteristik Variabel Penjelas Perbankan Sustain

\begin{tabular}{lllll}
\hline \multicolumn{1}{c}{ Variabel } & \multicolumn{1}{c}{ Min } & \multicolumn{1}{c}{ Mean } & \multicolumn{1}{c}{ Median } & \multicolumn{1}{c}{ Max } \\
\hline ROA & -0.07580 & 0.01986 & 0.01940 & 0.11200 \\
ROE & -14248.000 & -61.561 & 0.102 & 0.375 \\
CTD & 0.00000 & 0.20069 & 0.07767 & 0.99069 \\
LTA & 0.0000246 & 0.3535498 & 0.3651132 & 0.8116476 \\
DTA & 0.0000000 & 0.2312629 & 0.1028194 & 0.8631693 \\
CTA & 0.000000 & 0.100495 & 0.017451 & 0.958755 \\
\hline
\end{tabular}

Sumber Data: Hasil Pengolahan SPS 


\subsection{Model Regresi Logistik}

Model regresi Logistik dibentuk dari 393 baris data, 1 variabel dependen yaitu FSS, 6 variabel prediktor. Model regresi dibentuk dengan bantuan software $R$ dan fungsi glm. Hasil olah data menunjukkan nilai koefisien dan odds rasio untuk setiap variable. Tabel 4 menunjukkan ecara ringkas asilolah data dengan menggunakan regresi logistik. Tahapan selanjutnya yaitu melakukan uji simultan atau uji serentak. Uji simultan bertujuan untuk mengetahui hubungan variable prediktor secara keseluruhan terhadap variable respon. Tabel 5 menunjukkan hasil uji simultan

Tabel 4. Hasil Olah Data dengan Fungsi GLM.

\begin{tabular}{lcccc}
\hline \multicolumn{1}{c}{ Variabel } & Koefisien & Std. Error & P-value & Odds Ratio \\
\hline Intercept & -1.5020 & 0.002310 & 0.5153 & 0.222684346 \\
ROA & 0.18889 & 0.000057 & $0.0009 * * *$ & 1.207908075 \\
ROE & 0.0073 & 0.000595 & 0.9021 & 1.00732671 \\
CTD & -0.1804 & 0.049310 & 0.9708 & 0.83493617 \\
LTA & 0.7919 & 0.401700 & $0.04869 *$ & 2.207586859 \\
DTA & -0.4838 & 0.048890 & 0.32236 & 0.616436477 \\
CTA & -0.8671 & 0.007005 & 0.21580 & 0.420168272 \\
\hline
\end{tabular}

Sumber Data: Hasil Pengolahan SPS

Tabel 5. Hasil Uji Simultan

\begin{tabular}{ccc}
\hline & & -2 Log Likelihood \\
\hline Step & $\mathbf{1}$ & 256.0342 \\
& $\mathbf{2}$ & 256.0342 \\
& $\mathbf{3}$ & 256.0342 \\
\hline
\end{tabular}

Sumber Data: Hasil Pengolahan SPS

Hasil uji simultan menunjukkan bahwa nilai $-2 \log$ likelihood adalah $\mathrm{G}=$ 256.0304. Apabila nilai tersebut dibandingkan dengan nilai pada tabel $\chi f_{f, \alpha}^{2}$, maka nilai $\mathrm{G}$ masih lebih besar. Hal ini mengakibatkan hasil pengujian simultan menolak $H 0$. Artinya minimal ada satu parameter $\beta i \neq 0$. Sehingga dapat disimpulkan bahwa terdapat satu atau lebih variabel prediktor yang berpengaruh signifikan terhadap variabel respon. Pengujian ini didukung dengan uji parsial yang menunjukkan, bahawa dengan derajat kesalahn 5\% maka terdapat 2 variabel prediktor yang signifikan mempengaruhi vaariabel respon FSS. Kedua variabel tersebut yaitu variabel ROA dan variabel LTA. Penulisan model regresi logistik memungkinkan semua koefisien variabel disertakan. Akan tetapi untuk interpretasi secara parsial cukup dilakukan pada variabel yang signifikan berpengaruh. Berikut ini adalah model regresi logistik yang dapat dibentuk berdasarkan Tabel 4 .

$\pi(x)=\frac{\exp (-1.5020+0.18889+0.0073-0.1804+0.7919-0.4838-0.8671)}{1+\exp (-1.5020+0.18889+0.0073-0.1804+0.7919-0.4838-0.8671)}$ 


\subsection{Interpretasi Odds Rasio dan Pembahasan}

Interpretasi koefisien variabel yang dilakukan pada analisis regresi logistik berbeda dengan analisis regresi linier. Pada regresi logistik, interpretasi koefisien variabel menggunakan nilai Odds rasio setiap variabel. Berikut ini adalah interpretasi nilai odds rasio variabel yang signifikan pada model berdasarkan Tabel 4 .

a) Variabel ROA

Nilai odds rasio untuk variabel ROA adalah sebesar 1.2. Nilai ini mengindikasikan bahwa apabila suatu perbankan mempunyai nilai ROA yang lebih tinggi sebesar satu satuan maka bank tersebut mempunyai kecenderungan untuk lebih sustain sebesar 1.2 kali. Variabel ROA yang mempunyai pengaruh signifikan terhadap sustainability perbankan menunjukan bahwa perbankan mempunyai profitabilitas yang tinggi sehingga pengungkapan sustainability akan lebih baik. Hasil berikut didukung oleh penelitian yang dilakukan oleh Marwa (2015) yang mengatakan bahwa ROA berpengaruh terhadap sustainability perusahaan yang berarti menunjukan baiknya pengelolaan atau manajemen pengelolaan perusahaan secara keseluruhan. Penelitian lain yang dilakukan oleh Wahyuni (2014) yang menunjukan ROA, CAR, BOPO, dan FDR berpengaruh signifikan terhadap financial sustainability perbankan.

b) Variabel LTA

Nilai odds rasio untuk variabel LTA adalah sebesar 2.2. Artinya bahwa apabila suatu perbankan mempunyai nilai LTA yang lebih tinggi sebesar satu satuan maka bank tersebut mempunyai kecenderungan untuk lebih sustain sebesar 2.2 kali. Variabel LTA merupakan tingkat likuiditas yang dimiliki bank terkait kemampuan bank dalam memenuhi kredit nasabah atau penyaluran pembiayaan kepada masyarakat terhadap total asset yang dimiliki oleh bank. Susanthi (2010) juga menyimpulkan bahwa LTA berpengaruh terhadap profitabilitas BPD di Denpasar.

\subsection{Kesesuaian Prediksi Regresi Logistik}

Ukuran untuk menguji kesesuian prediksi regresi logistik ditunjukkan dengan beberapa metode. Metode-metode yang digunakan dalam penelitian ini antara lain yaitu spesifikasi model, model plot Receiver Operating Characteristics (ROC) dan missklasifikasi model dengan data aktual. Apabila dilakukan uji kesesuaian model dengan fungsi "specificity" diperoleh ilia 91.77\%. Berikut fungsi yang digunakan;

specificity(inputData\$kategori, predicted, threshold = optCutOff)

[1] 0.9177489 
Apabila dengan menggunakan metode ROC diperoleh kesesuain sebesar 65\%. Berikut perintah dan hasil output dari fungsi ROC ditunjukkan pada Gambar 2. plotROC(inputData\$kategori, predicted)

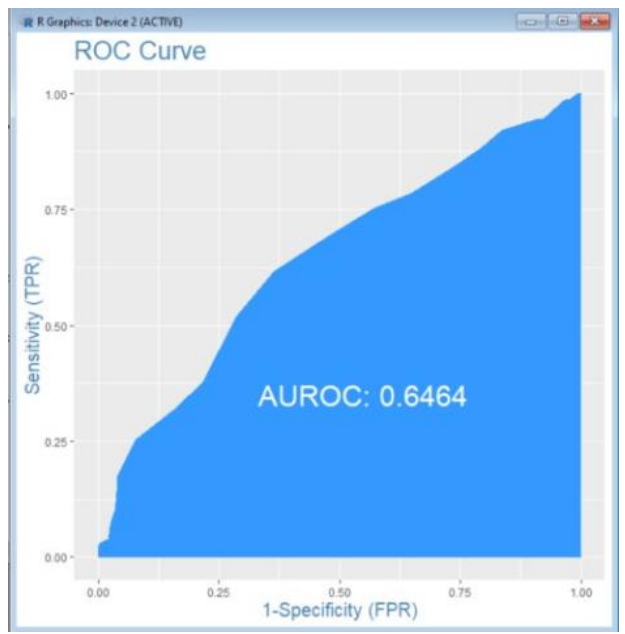

Gambar 2. Plot ROC

\section{KESIMPULAN DAN SARAN}

Hasil penelitian tentang pemodelan regresi logistik pada analisis sustainability perbankan di Indonesia menunjukkan beberapa variabel yang signifikan. Variabel ROA dan dan variabel LTA merupakan dua variabel yang signifikan dalam menentukan sustainability perbankan. Nilai odd ratio dari variabel ROA adalah sebesar 1.2. Nilai odd ratio dari variabel LTA adalah sebesar 2.2. Apabila suatu bank mempunyai nilai ROA dan LTA satu satuan lebih tinggi dengan bank lainnya, maka bank tersebut mempunyai kecenderungan untuk bias sustain lebih baik daripada dengan bank yang nilai ROA dan LTA lebh rendah.

Penilitian ini mempunyai beberapa kelemahan, diantaranya adalah tidak semua rasio keuangan digunakan dalam peneliitian. Hal ini bias menjadi perbaikan untuk penelitian selanjutnya agar dapat menggunakan lebih banyak rasio keuangan. Semakin banyak rasio keuangan yang digunakan maka akan semakin mendekati kondisi keuangan perbankan yang sesungguhnya. Selebihnya, analisis regresi logistik yang digunakan mampu menunjukkan performa sebesar kurang lebih $65 \%$. Meskipun nilai tersebut dianggap cukup, akan tetapi akan lebih baik jika diolah dengan metode lain yang mungkin mendapatkan nilai performa yang lebih tinggi. Beberapa metode lain seperti pendekatan Neural Network, Bayesian dan lainnya. 


\section{DAFTAR PUSTAKA}

Almilia, L. S., dan Shonhadji, N. 2009. Faktor-Faktor yang Mempengaruhi Financial Sustainability Ratio pada Bank Umum Swast Nasional Non Devisa Periode. 11.

Asnawi, N., dan Masyhuri. 2011. Metodologi Riset Manajemen Pemasaran. Malang: UIN Maliki Press.

Ayyubi, S. E., Anggraeni, L., dan Mahiswari, A. D. 2017. Pengaruh Bank Syariah terhadap Pertumbuhan Ekonomi di Indonesia . Jurnal Al-Muzara'ah, 88-106.

Bank Indonesia. 1998. Undang-Undang No.10 Tahun 1998 Tentang Perubahan Terhadap Undang-Undang No.7 Tahun 1992. Jakarta.

Bourkhis , K., dan Nabi, M. S. 2013. Islamic and conventional banks' soundness during the 2007-2008 financial crisis. Review Financial Economics, 68-77.

Chong, B. S., dan Liu, M.-H. 2009. Islamic banking: Interest-free or interest-based? Pacific-Basin Finance Journal, 125-144.

Hamdi, A. S., dan Bahruddin, E. 2014. Metode Penelitian Kuantitatif Aplikasi Dalam Pendidikan. Yogyakarta: Deepublish.

Hasan, M. M., dan Dridi, J. 2011. The Effects of the Global Crisis on Islamic and Conventional Banks: A Comparative Study. . IMF Working Paper 10/201.

Hosmer, D. W., dan Lemeshow, S. 2000. Applied Logistic Regression (Second Edition). New York: John. Wiley dan Sond, INC.Juanda, B (2009). EKONOMETRIKA: Pemodelan dan Pendugaan. IPB Press

Ifham, A. 2015. Ini Lho Bank Syariah; Memahami Bank Syariah dengan Mudah. Jakartaa: PT Gramedia Pustaka Utama.

Ismail. 2016. Perbankan Syariah. Jakarta: PRENADAMEDIA GROUP.

Johnes, J., Izzeldin, M., dan Pappas, V. 2014. A comparison of performance of Islamic and conventional banks 2004-2009. Journal of Economic Behavior dan Organization, 93-107.

Khan, F. 2010. How 'Islamic' is Islamic Banking? Journal of Economic Behavior dan Organization, 805-820.

Marwa, N., dan Aziakpono, M. (2015). Financial sustainability of Tanzanian saving and credit cooperatives. International Journal of Social Economics, 42(10), 870-887.

Rafsanjani, H., dan Sukmana, R. 2014. Pengaruh Perbankan Atas Pertumbuhan Ekonomi: Studi Kasus Bank Konvensional dan Bank Syariah di Indonesia. Jurnal Aplikas Manajemen, 492-502.

Saragih, A. F. 2013. Analisis Perbandingan Kinerja Keuangan Antara Bank Syariah. Jurnal Akuntansiku, 1-15.

Sho'imah, L., Darminto, dan Nuzula, N. F. 2015. Analisis Rasio Keuangan Perbankan Sebagai Alat Untuk Mengevaluasi Kinerja Keuangan Bank (studi pada PT Bank Tabungan Negara ). Jurnal Administrasi Bisnis, 1-10.

Susanthi, Ari. 2010. Pengaruh Loan to Deposit ratio, Capital Adequacy Ratio, dan Leverage Management terhadap Profitabilitas pada PT Bank Pembangunan Daerah Bali Kantor Pusat Denpasar. Jurusan Manajemen Fakultas Ekonomi Universitas Udayana, Denpasar

Sylvanus Ikhide. 2017. Financing and financial Sustainability: Evidence from selected southern Africa development community microfinance institutions. 
Thayib, B., Murni, S., dan Maramais, J. 2017. Analisis PErbandingan Kinerja Keuangan Bank Syariah dan Bank Konvensional. JURNAL EMBA: JURNAL RISET EKONOMI, MANAJEMEN, BISNIS DAN AKUNTANSI, 1759-1768.

Usanti, T. P., dan Shomad, A. 2016. Hukum Perbankan. Jakarta: KENCANA.

Vivin, Y. A., dan Wahono, B. 2017. ANALISIS PERBANDINGAN KINERJA

KEUANGAN BANK UMUM. $e$ - Jurnal Riset Manajemen-unisma, 15-28. 